\title{
Model Epidemi SICKR pada Penyebaran Penyakit Hepatitis B dan Kanker Hati
}

\author{
Nur 'Ain Supu1', Saltina², Karmila Palalu ${ }^{3}$, Rizki Ismail ${ }^{4}$ \\ 1,2,3,4 Jurusan Matematika, Fakultas MIPA, Universitas Negeri Gorontalo, \\ Jl. Prof. Dr. Ing. B. J. Habibie, Tilongkabila, Kabupaten Bone Bolango, Gorontalo 96119, Indonesia \\ Email Korespondensi:nurainsupu23@gmail.com
}

\begin{abstract}
ABSTRAK
Infeksi virus hepatitis B merupakan penyakit infeksi disebabkan oleh virus hepatitis B (VHB) yang dapat menimbulkan peradangan dan bahkan kerusakan sel-sel hati atau hepatitis. Penyebaran virus hepatitis B dapat terjadi secara horizontal maupun vertical. Penelitian ini bertujuan untuk menjelaskan model epidemik SICKR pada penyebaran penyakit hepatitis B dan kanker hati. Model yang terbentuk akan dianalisis dengan menentukan titik tetap, menentukan bilangan reproduksi dasar, menganalisis kestabilan titik tetap dan melakukan simulasi. Hasil yang diperoleh yaitu dapat dibentuk model SICKR (Susceptible, Infected, Cronis, Kanker, dan Recovered). Model yang diperoleh merupakan sistem persamaan differensial non-linear. Kestabilan titik tetap bebas penyakit akan stabil saat bilangan reproduksi dasar kurang dari nol, sedangkan untuk titik tetap endemik akan stabil jika bilangan reproduksi dasar lebih dari nol.
\end{abstract}

\section{Kata Kunci:}

Model Epidemi; Hepatitis B; Kanker Hati

\section{Pendahuluan}

Hepatitis B adalah salah satu penyakit yang menular yang menyerang hati dan dapat menyebabkan penyakit akut dan kronis. Hapatitis B adalah salah satu masalah kesehatan global utama dan jenis Hepatitis yang paling serius, Diperkirakan sekitar 780.000 orang meninggal setiap tahun akibat hepatitis B, seperti sirosis hati dan kanker hati [1][2].

Hepatitis adalah peradangan pada hati yang disebabkan oleh virus hepatitis B (VHB) sehingga hati tidak bisa menjalankan fungsinya dengan optimal. Ada berbagai macam jenis virus hepatitis yaitu hepatitis A, B, C, D dan E. Salah satu yang harus diwaspadai oleh tenaga kesehatan yang bekerja di Rumah sakit adalah hepatitis $\mathrm{B}$ dan hepatitis C [3]. Infeksi virus hepatitis B dapat menimbulkan peradangan dan bahkan kerusakan sel-sel hati atau hepatitis [4].

Penyebaran virus hepatitis B dapat terjadi secara horizontal maupun vertikal. Penularan secara horizontal dapat terjadi melalui kulit atau melalui selaput lendir, sedangkan penularan secara vertical terjadi dari seorang pengidap yang hamil kepada bayi yang dilahirkannya [5]. Berbagai ragam bentuk perjalanan klinis infeksi hepatitis B yaitu bisa berupa hepatitis akut, sembuh, atau berlanjut menjadi hepatitis kronis inaktif, atau berlanjut menjadi kanker hati atau sirosis hati [5]. Riset kesehatan dasar tahun 2013 menyatakan bahwa sekitar 7,2\% penduduk indonesia terinfeksi hepatitis B , dengan $50 \%$ 
diantaranya berpotensi kronis dan $10 \%$ berpotensi fribosis hati yang dapat menyebabkan kanker hati [6].

Permasalahan yang ada dalam lingkungan kehidupan dapat ditransformasikan dalam model matematika [7] dengan menggunakan beberapa asumsi. Dari model matematika yang ada selanjutnya dapat dianalisis perilaku-perilaku di dalamnya. Dengan mempertimbangkan tingkat penyebaran virus hepatitis B (VHB) menjadi kanker hati, diperkenalkan model SICKR diharapkan dapat membantu mengetahui tingkat penyebaran virus hepatitis B (VHB) dan kanker hati.

Beberapa peneliti telah mengkaji model penyebaran penyakit hepatitis $B$, salah satunya adalah pengembangan model SIR pada infeksi virus hepatitis B (VHB) [8]. Selain itu, terdapat pembahasan model matematika yang mengaitkan antara hepatitis $\mathrm{B}$ dan kanker Hati [9].

Dalam penelitian ini kami mengkaji model epidemik penularan penyakit Hepatitis B dan kanker hati yang dimodelkan dalam bentuk SICKR. Model SICKR ini digunakan untuk mengetahui penyebaran penyakit hepatitis B dan kanker hati. Dari model tersebut akan dicari titik tetap tetap bebas penyakit dan titik tetap endemik kemudian akan dianalisis titik kestabilannya apakah stabil atau tidak. Selain itu, akan diberikan simulasi dari model penyebaran hepatitis B dan kanker hati untuk memperkuat hasil analisis.

\section{Metode}

Metode yang dilakukan pada penelitian ini adalah studi literatur dengan menelusuri dan mempelajari jurnal dan referensi yang berkaitan dengan model matematika penyebaran pengguna narkoba. Langkah-langkah yang dilakukan adalah sebagai berikut:

1. Menentukan Asumsi

2. Membentuk model matematika

3. Menentukan titik tetap model

4. Menentukan bilangan reproduksi dasar

5. Melakukan analisis kestabilan titik tetap

6. Melakukan simulasi

7. Kesimpulan

\section{Hasil dan Pembahasan}

\subsection{Model Matematika}

Model yang akan di bahas dalam penelitian ini adalah model epidemi pada penularan penyakit hepatitis B dan kanker hati. Populasi manusia pada waktu (t) terbagi menjadi lima populasi yaitu populasi yang rentan terhadap penyakit (S), populasi infected atau yang terinfeksi penyakit (I), populasi cronis yaitu populasi individu yang berpindah dari populasi terinfeksi dan menjadi terinfeksi cronis (C), populasi kanker yaitu individu yang mengalami perkembangan penyakit dari terinfeksi cronis berpindah ke populasi kanker $(\mathrm{K})$ dan recovered $(\mathrm{R})$ yang berarti kelas yang berisi individu-induvidu yang telah sembuh dari penyakit.

Asumsi-asumsi yang digunakan pada model SICKR sebagai berikut: 
1. Populasi penduduk konstan dan tertutup, dimana laju kelahiran sama dengan laju kematian.

2. Populasi bersifat homogen, artinya setiap orang memliki resiko yang sama untuk tertular virus Hepatitis B.

3. Individu yang belum terserang penyakit masuk ke dalam kelas $S$

4. Virus menular melalui interaksi antara individu $S$ dan I.

5. Individu pada kelas I dapat mengalami perkembangan infeksi menjadi pembawa (kronis) yang kemudian masuk ke kelas $\mathrm{C}$, namun ada sebagian yang langsung sembuh dan masuk ke kelas $\mathrm{R}$.

6. Individu pada kelas $C$ dapat mengalami perkembangan penyakit dan masuk ke kelas $\mathrm{K}$, namun sebagian kecil dapat sembuh dan berpindah ke kelas $\mathrm{R}$

7. Individu pada kelas $\mathrm{K}$ sudah tidak dapat sembuh lagi.

8. Individu yang telah sembuh tidak akan tertular virus Hepatitis B

9. Vaksinasi ampuh $100 \%$

Secara skematis dinamika populasi model epidemik SICKR pada penyebaran hepatitis B dan kanker hati dapat dilihat pada Gambar 1.

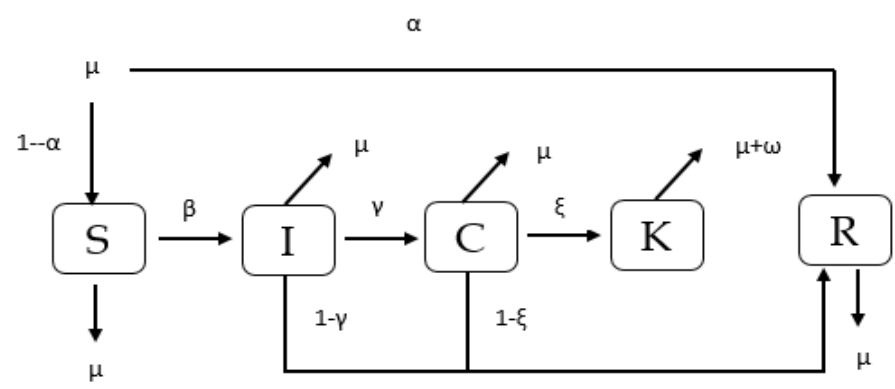

Gambar 1. Model SICKR pada penyebaran penyakit Hepatitis B dan Kanker Hati

Berdasarkan Gambar 1 diperoleh model dalam bentuk sistem persamaan ini sebagai berikut:

$$
\begin{aligned}
& S(t)=(1-\alpha) \mu N-\beta S \frac{I}{N}-\mu S \\
& I(t)=\beta S \frac{I}{N}-\gamma I-(I-\gamma) I-\mu I \\
& C(t)=\gamma I-\xi C-(1-\xi) C-\mu C \\
& K(t)=\xi C-(\mu+\omega) K \\
& R(t)=\alpha \mu N+(1-\gamma) I+(1-\xi) C-\mu R
\end{aligned}
$$

Keterangan parameter disajikan pada Tabel 1.

Tabel 1. Keterangan parameter

\begin{tabular}{cl}
\hline Parameter & \multicolumn{1}{c}{ Keterangan } \\
\hline$\mu$ & Laju kelahiran dan laju kematian \\
$\alpha$ & Laju vaksinasi \\
$\beta$ & Laju interaksi individu pada populasi rentan dan populasi terinfeksi \\
$\Upsilon$ & Laju perpindahan individu pada populasi rentan manjadi terinfeksi kronis \\
$\xi$ & Laju perpindahan individu pada populasi yang terinfeksi kronis manjadi \\
$\omega$ & kanker \\
\hline
\end{tabular}




\subsection{Penentuan Titik Kesetimbangan}

Dari hasil analisis di dapat dua jenis titik tetap yaitu titik kesetimbangan bebas penyakit dan titik kesetimbangan endemik.

Titik tetap bebas penyakit dapat dinyatakan dalam bentuk:

$$
E_{1}^{* *}=(s, i, c, k, r)=(\mathrm{s} *, 0,0,0, \mathrm{r} *)
$$

Dengan

$$
\begin{aligned}
& \mathrm{s} *=(1-\alpha) \\
& \mathrm{r} *=\alpha
\end{aligned}
$$

Titik tetap endemik:

$$
E_{2}{ }^{* *}=(s, i, c, k, r)=\left(\mathrm{s}^{*}, \mathrm{i}^{*}, \mathrm{C}^{*}, \mathrm{k}^{*}, \mathrm{r}^{*}\right)
$$

Dengan :

$$
\begin{aligned}
& \mathrm{s} *=\frac{\mu+1}{\beta} \\
& \mathrm{i} *=-\frac{\mu(1+\beta(1-\alpha)+\mu)}{(\mu+1) \beta} \\
& \mathrm{c} *=-\frac{(1+\beta(1-\alpha)+\mu) \mu \gamma}{(\mu+1)^{2} \beta} \\
& \mathrm{k} *=\frac{\mu \gamma \xi(1+\beta(1-\alpha)+\mu)}{\beta\left(1+\mu^{2}\right)(\omega+\mu)} \\
& \mathrm{r} *=\frac{(\mu+1)(-1+(1-\gamma) \mu+\gamma \xi)+\beta(1+\mu-\mu \gamma+\alpha \mu(1+\gamma+\mu)+(1-\alpha) \gamma \xi}{\beta\left(1+\mu^{2}\right)}
\end{aligned}
$$

\subsection{Bilangan Reproduksi Dasar $\left(R_{0}\right)$}

Bilangan reproduksi dasar diperoleh dengan menggunakan metode matriks next generation [10][11], dari model yang telah dibentuk sehingga diperoleh bilangan reproduksi dasar sebagai berikut:

$$
R_{0}=\frac{\beta(1-\alpha)}{(\mu+1)(\mu+\omega)}
$$

\subsection{Ananlisis Ksetabilan Titik Tetap}

Model epidemi yang diperoleh dari penyebaran penyakit hepatitis B dan kanker hati diatas merupakan sistem persamaan diferensial non linear [12][13] .Untuk menganalisis kestabilan titik tetap suatu sistem persamaan differensial nonlinear, dapat dilakukan dengan melinearkan persamaan differensialnya. Analisis kestabilan titik tetap dapat ditentukan dengan cara menentukan nilai eigen dari matriks Jacobian sistem.

Teorema 1. Titik tetap penyakit akan stabil jika $R_{0}<1$ dan titik tetap endemic akan stabil jika $R_{0}>1$. 


\section{Bukti:}

Matriks Jacobian dari sistem (1) adalah:

$$
J=\left(\begin{array}{ccccc}
-\beta i-\mu & -\beta s & 0 & 0 & 0 \\
\beta i & \beta s-\mu-1 & 0 & 0 & 0 \\
0 & \gamma & -1-\mu & 0 & 0 \\
0 & 0 & \xi & -\mu-\omega & 0 \\
0 & 1-\gamma & 1-\xi & 0 & -\mu
\end{array}\right)
$$

Untuk memperoleh kestabilan sistem dititik $E_{1}{ }^{* *}$ terlebih dahulu dilakukan pelinearan disekitar titik tetap $E_{1}{ }^{* *}$ sehingga diperoleh matriks Jacobian sebagai berikut:

$$
\mathrm{J} E_{1}{ }^{* *}=\left(\begin{array}{ccccc}
-\mu & -\beta(1-\alpha) & 0 & 0 & 0 \\
0 & \beta(1-\alpha)-\mu-1 & 0 & 0 & 0 \\
0 & \gamma & -1-\mu & 0 & 0 \\
0 & 0 & \xi & -\mu-\omega & 0 \\
0 & 1-\gamma & 1-\xi & 0 & -\mu
\end{array}\right)
$$

Dengan menyelesaikan persamaan kerakteristik

$$
\left.\operatorname{det}\left(\lambda I-J E_{1}^{* *}\right)=0\right)
$$

Maka akan didapatkan nilai-nilai eigen dari matriks $\mathrm{J}\left(E_{1}{ }^{* *}\right)$ yaitu :

$$
\begin{gathered}
\lambda_{1}=-\mu \\
\lambda_{2}=-\alpha \beta+\beta-\mu-1 \\
\lambda_{3}=-1-\mu \\
\lambda_{4}=-\mu-\omega \\
\lambda_{5}=-\mu
\end{gathered}
$$

Karena semua parameter bernilai posistif maka diperoleh $\lambda_{1}, \lambda_{3}, \lambda_{4}, \lambda_{5}<0$. Agar titik bebas penyakit stabil maka kita perlu menunjukkan bahwa $\lambda_{2}<0$.

Bukti:

$$
\begin{gathered}
\lambda_{2}=-\alpha \beta+\beta-\mu-1 \\
-\alpha \beta+\beta-\mu-1<0 \\
\beta(1-\alpha)-(\mu+1)<0 \\
\beta(1-\alpha)<\mu+1 .
\end{gathered}
$$

berdasarkan bilangan reproduksi dasar, titik tetap bebas penyakit akan stabil jika $R_{0}<1$, maka:

$$
\begin{gathered}
R_{0}=\frac{\beta(1-\alpha)}{(\mu+1)(\mu+\omega)} \\
\frac{\beta(1-\alpha)}{(\mu+1)(\mu+\omega)}<1 \\
\beta(1-\alpha)<(\mu+1)(\mu+\omega) .
\end{gathered}
$$

Berdasarkan persamaan (9) maka terbukti bahwa persamaan (8) $<0$ sehingga $\lambda_{2}<0$, dimana:

$$
\beta(1-\alpha)-(\mu+1)<1
$$


Dari nilai eigen yang diperoleh telah ditunjukkan $\lambda_{2}$ bernilai negatif maka $\lambda_{1}, \lambda_{2}, \lambda_{3}$, $\lambda_{4}, \lambda_{5}<0$ sehingga titik tetap bebas penyakit pada penyebaran penyakit hepatitis $B$ dan kanker hati diatas adalah stabil.

Untuk kestabilan sistem di titik $E_{2}{ }^{* *}$ dilakukan pelinearan sehingga diperoleh matriks Jacobian $E_{2}{ }^{* *}$ sebagai berikut:

$$
\mathrm{J} E_{2}{ }^{* *}=\left(\begin{array}{ccccc}
\frac{\mu(\alpha \beta-\beta+\mu+1)}{\mu+1}-\mu & 1-\mu & 0 & 0 & 0 \\
\frac{\mu(\alpha \beta-\beta+\mu+1)}{(\mu+1)} & 0 & 0 & 0 & 0 \\
0 & \gamma & -1-\mu & 0 & 0 \\
0 & 0 & \xi & -\mu-\omega & 0 \\
0 & 1-\gamma & 1-\xi & 0 & -\mu
\end{array}\right)
$$

Dengan menyelesaikan persamaan kerakteristik

$$
\operatorname{det}\left(\lambda I-J E_{2}^{* *}\right)=0
$$

Sehingga diperoleh persamaan:

$$
\left(\lambda+A_{33}\right)\left(\lambda+A_{44}\right)\left(\lambda+A_{55}\right)\left(\lambda^{2}-A_{11} \lambda-A_{12} A_{21}\right)=0
$$

Dari persamaan diatas didapatkan nilai lima nilai eigen. Tiga nilai eigen sebagai berikut

$$
\begin{gathered}
\lambda_{1}=-1-\mu \\
\lambda_{2}=-\mu-\omega \\
\lambda_{3}=-\mu
\end{gathered}
$$

Karena semua nilai parameter yang digunakan positif maka $\lambda_{1}, \lambda_{2}, \lambda_{3}$ negatif. Untuk dua nilai eigen lainnya akan diiperoleh dengan menganalisis persamaan karakteristik berikut:

$$
\lambda^{2}-A_{11} \lambda-A_{12} A_{21}=0
$$

Dimana:

$$
\begin{aligned}
& A_{11}=\frac{\mu(\alpha \beta-\beta+\mu+1)}{\mu+1}-\mu \\
& A_{12}=1-\mu \\
& A_{21}=\frac{\mu(\alpha \beta-\beta+\mu+1)}{(\mu+1)}
\end{aligned}
$$

Berdasarkan persamaan (13) kita akan menunjukkan bahwa:

$\lambda_{4} \lambda_{5}=-A_{12} A_{21}$

$\lambda_{4}+\lambda_{5}=A_{11}$

Untuk persamaan (14) dimana $\lambda_{4}+\lambda_{5}$ akan ditunjukan bahwa $\lambda_{4}<0$ atau $\lambda_{5}<0$, maka

$$
\begin{aligned}
\lambda_{4}+\lambda_{5}= & \frac{-\mu(\alpha \beta-\beta+\mu+1)}{\mu+1}+\mu \\
& \frac{-\mu(\alpha \beta-\beta)}{\mu+1}>1
\end{aligned}
$$




$$
\begin{gathered}
\frac{\mu \beta(1-\alpha)}{\mu+1}>1 \\
\beta(1-\alpha)>\frac{\mu+1}{\mu} .
\end{gathered}
$$

Berdasarkan bilangan reproduksi dasar bahwa titik tetap endemik akan stabil jika $R_{0}>$ 1, maka:

$$
\begin{gathered}
R_{0}>1 \\
\frac{\beta(1-\alpha)}{(\mu+1)(\mu+\omega)}>1 \\
\beta(1-\alpha)>(\mu+1)(\mu+\omega)
\end{gathered}
$$

Berdasarkan permasamaan (15) dan (16) didapatkan :

Maka:

$$
\beta(1-\alpha)>\frac{\mu+1}{-\mu} \text { dan } \beta(1-\alpha)>(\mu+1)(\mu+\omega)
$$

$$
\beta(1-\alpha)>(\mu+1)(\mu+\omega)>\frac{\mu+1}{-\mu}
$$

Sehingga $\beta(1-\alpha)>0$ dan $\lambda_{4}<0$.

Setelah itu kita akan menunjukan bahwa $\lambda_{4} \lambda_{5}=-A_{12} A_{21}$

Bukti:

$$
\begin{gathered}
\lambda_{4} \lambda_{5}=-A_{12} A_{21} \\
=-\left(\frac{\mu(\alpha \beta-\beta+\mu+1)}{(\mu+1)}\right)(1-\mu) \\
=\mu(\beta-\alpha \beta-\mu-1) \\
=\mu(\beta-(\alpha \beta+\mu+1))
\end{gathered}
$$

Berdasarkan bilangan reproduksi dasar bahwa titik tetap endemik akan stabil jika $R_{0}>1$, maka:

$$
\begin{gathered}
R_{0}>1 \\
\frac{(\beta-\alpha \beta)}{(\mu+1)(\mu+\omega)}>1 \\
\beta>(\mu+1)(\mu+\omega)+\alpha \beta
\end{gathered}
$$

Dari persamaan (18) kita mendapatkan $\beta>(\mu+1)(\mu+\omega)+\alpha \beta$ sehingga persamaan (17) $>0$, Maka $\lambda_{4} \lambda_{5}>0$, Karena $\lambda_{4}<0$ maka $\lambda_{5}<0$. Jadi $\lambda_{1}, \lambda_{3}, \lambda_{4}, \lambda_{5}<0$ maka titik tetap endemik stabil.

\subsection{Simulasi}

Selanjutnya akan dilakukan simulasi nilai-nilai parameter yang terdapat di dalam model dengan populasi awal $\mathrm{S}(0)=100, \mathrm{I}(0)=30, \mathrm{C}(0)=20, \mathrm{~K}(0)=10 \mathrm{R}(0)=20$. Adapun nilai parameter yang akan digunakan pada simulasi pertama dapat dilihat pada Tabel 2. 
ISBN: 978-623-93208-1-2

Table 2. Nilai parameter simulasi pertama

\begin{tabular}{clc}
\hline Parameter & \multicolumn{1}{c}{ Keterangan } & Nilai \\
\hline$\mu$ & Laju kelahiran dan laju kematian & 0.3 \\
$\alpha$ & $\begin{array}{l}\text { Laju vaksinasi } \\
\text { Laju perpindahan individu pada populasi terinfeksi menjadi } \\
\text { terinfeksi kronis }\end{array}$ & 0.4 \\
$\gamma$ & Laju perpindahan individu pada populasi yang terinfeksi & 0.6 \\
$\xi$ & kronis menjadi kanker & 0.4 \\
$\omega$ & Laju kematian karena penyakit kanker & 0.2 \\
\hline
\end{tabular}

Untuk mengetahui penyebaran penyakit hepatitis B dan kanker hati, dibuat perbedaan laju pada parameter $\beta$ pada tabel berikut:

Tabel 3. variasi nilai $\beta$ pada saat $R_{0}<1$

\begin{tabular}{cc}
\hline$\beta$ & $\mathrm{R}_{0}$ \\
\hline 0.1 & 0.184615 \\
0.2 & 0.461538 \\
0.7 & 0.646154 \\
0.9 & 0.830769 \\
\hline
\end{tabular}

Diperoleh plot sebagai berikut:
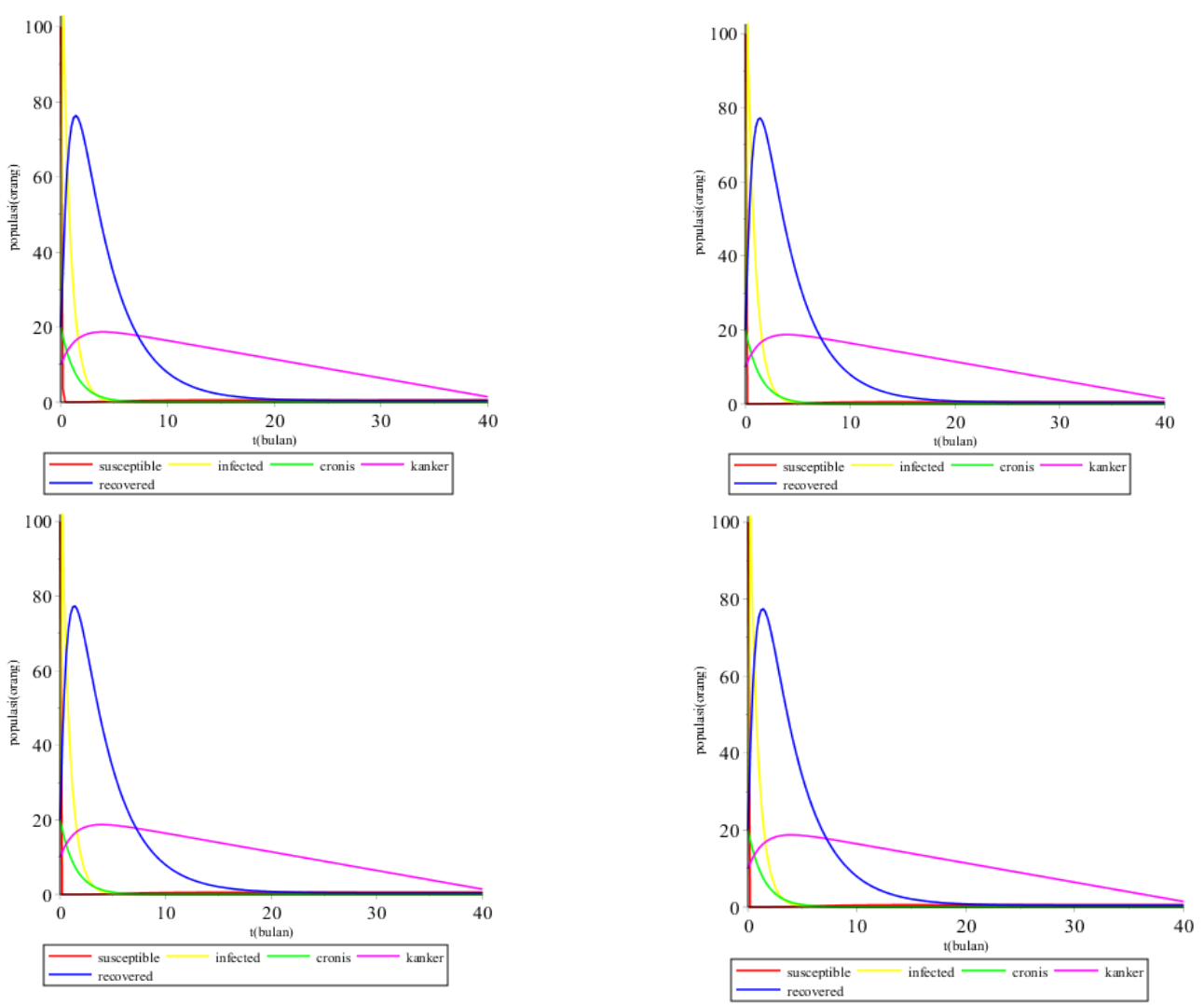

Gambar 2. Simulasi model SICKR pada saat $R_{0}<1$ dengan nilai $\beta=0.1,0.2,0.7,0.9$ 
Dari Gambar 2 terlihat bahwa populasi rentan mengalami kenaikan pada kondisi awal, hal ini terjadi karena adanya penambahan individu pada populasi rentan. kemudian populasi rentan mengalami penurunan karena sebagian individu rentan menjadi terinfeksi dan sebagian individu meninggal secara alami. Setelah mengalami penurunan populasi rentan tidak mengalami perubahan (konstan) pada saat $t$ tertentu.

Dari Gambar 2 terlihat bahwa individu terinfeksi mengalami kenaikan pada kondisi awal, hal ini terjadi karena adanya penambahan individu terinfeksi dari populasi rentan. Kemudian populasi terinfeksi mengalami penurunan karena sebagian individu pada populasi terinfeksi berpindah ke populasi infeksi cronis dan sebagian meninggal secara alami dan berpindah ke populasi recovered atau sembuh. Setelah itu populasi terinfeksi akan konstan pada $t$ tertentu.

Dari Gambar 2 terlihat bahwa populasi teinfeksi cronis mengalami kenaikan pada kondisi awal, hal ini disebabkan karena adanya penambahan individu dari populasi terinfeksi. Kemudian populasi terinfeksi cronis mengalami penurunan, hal ini disebabkan karena sebagian individu pada populasi infeksi cronis berpindah ke kelas kanker, sebagian meninggal secara alami dan individu lainnya sembuh dan berpindah kekelas recovered. Pada saat $t$ terterntu populasi infeksi cronis akan konstan di titik 0 . Dari Gambar 2 terlihat bahwa populasi kanker mengalami kenaikan pada kondisi awal, hal ini disebabkan karena adanya penambahan individu dari populasi terinfeksi cronis. Setelah itu populasi kanker mengalami penurunan karena individu-individu pada populasi kanker mengalami kematian secara alami dan kematian karena penyakit sampai pada $t$ tertentu populasi penyakit kanker menghilang.

Dari Gambar 2 terlihat bahwa populasi sembuh atau recovered mengalami kenaikan pada kondisi awal, hal ini disebabkan karena adanya penambahan individu dari populasi terinfeksi, populasi teninfeksi cronis dan individu yang telah divaksinasi. Kemudian populasi recovered akan mengalami penurunan, hal ini disebabkan sebagian individu mengalami kematian secara alami. Setelah itu populasi recovered atau sembuh akan konstan pada $t$ tertentu.

Untuk simulasi kedua, adapun nilai parameter yang akan digunakan adalah

Tabel 4. Nilai parameter untuk simulasi $R_{0}>1$

\begin{tabular}{clc}
\hline Parameter & \multicolumn{1}{c}{ Keterangan } & Nilai \\
\hline$\mu$ & Laju kelahiran dan laju kematian & 0.02 \\
$\alpha$ & Laju vaksinasi & 0.4 \\
$\gamma$ & $\begin{array}{l}\text { Laju perpindahan individu pada populasi } \\
\text { rentan menjadi terinfeksi kronis }\end{array}$ & 0.6 \\
$\xi$ & $\begin{array}{l}\text { Laju perpindahan individu pada populasi } \\
\text { yang terinfeksi kronis menjadi kanker }\end{array}$ & 0.7 \\
$\omega$ & Laju kematian karena penyakit kanker & 0.0 .3 \\
\hline
\end{tabular}


Untuk mengetahui penyebaran penyakit hepatitis B dan kanker hati, dibuat perbedaan laju pada parameter $\beta$ pada tabel berikut:

Tabel variasi nilai $\beta$ pada saat $R_{0}>1$

\begin{tabular}{cc}
\hline$\beta$ & $\mathrm{R}_{0}$ \\
\hline 0.2 & 1.568627 \\
0.3 & 2.352941 \\
0.5 & 3.921569 \\
0.6 & 4.705882 \\
\hline
\end{tabular}

Diperoleh plot sebagai berikut:
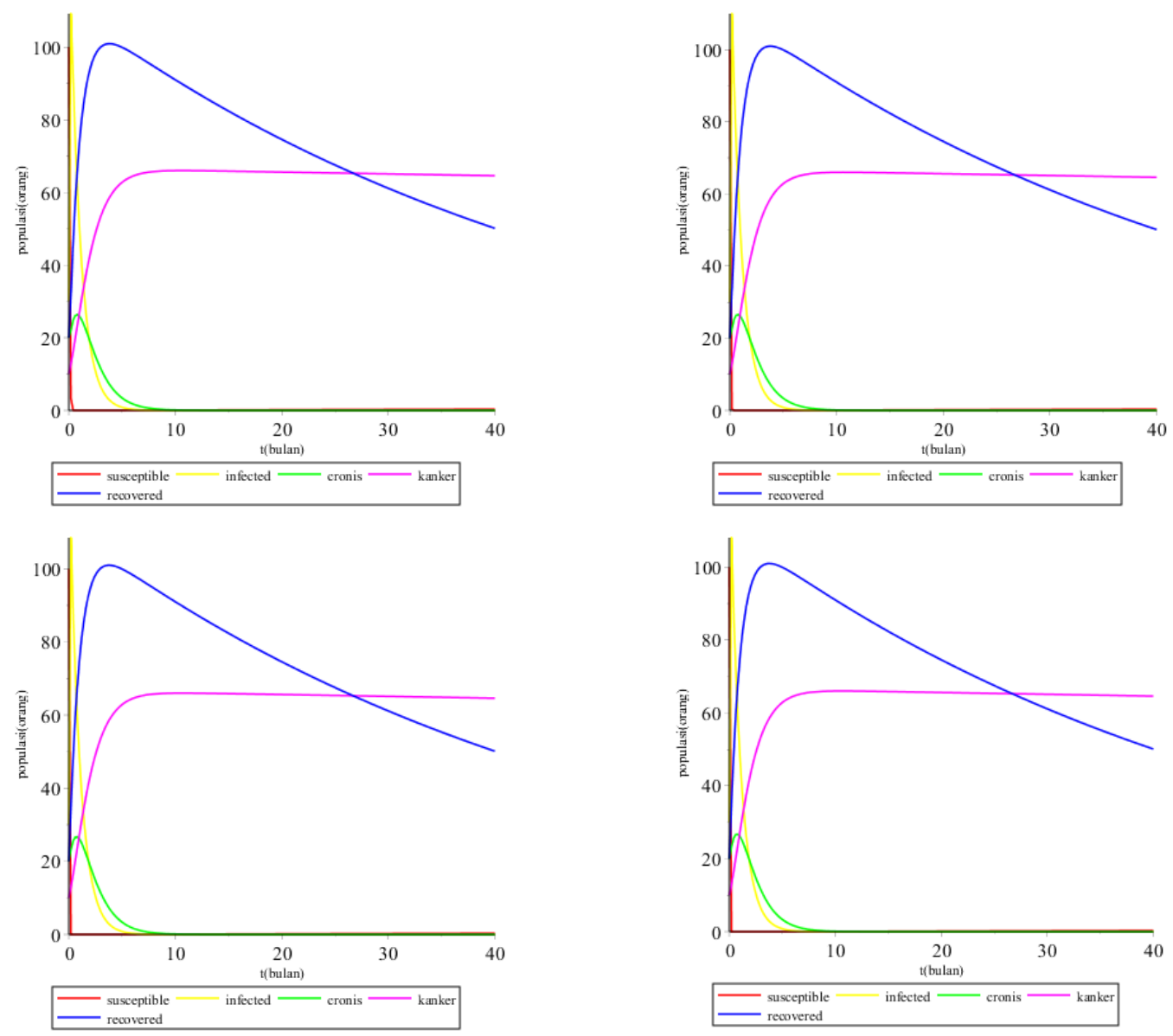

Gambar 3. Simulasi model SICKR pada saat $R_{0}>1$ dengan nilai $\beta=0.2,0.3,0.5,0.6$

Dari Gambar 3 terlihat bahwa populasi rentan mengalami kenaikan pada kondisi awal, hal ini terjadi karena adanya penambahan individu pada populasi rentan. kemudian populasi rentan mengalami penurunan karena sebagian individu rentan menjadi terinfeksi dan sebagian individu meninggal secara alami. Setelah mengalami penurunan populasi rentan tidak mengalami perubahan (konstan) pada $t$ tertentu. 
Dari Gambar 3 terlihat bahwa individu terinfeksi mengalami kenaikan pada kondisi awal, hal ini terjadi karena adanya penambahan individu terinfeksi dari populasi rentan. Kemudian populasi terinfeksi mengalami penurunan karena sebagian individu pada populasi terinfeksi berpindah ke populasi infeksi cronis dan sebagian meninggal secara alami dan berpindah ke populasi recovered atau sembuh. Setelah itu populasi terinfeksi akan konstan dititik 0 pada $t$ tertentu.

Dari Gambar 3 terlihat bahwa populasi teinfeksi cronis mengalami kenaikan pada kondisi awal, hal ini disebabkan karena adanya penambahan individu dari populasi terinfeksi. Kemudian populasi terinfeksi cronis mengalami penurunan, hal ini disebabkan karena sebagian individu pada populasi infeksi cronis berpindah ke kelas kanker, sebagian meninggal secara alami dan individu lainnya sembuh dan berpindah kekelas recovered. Pada saat $t$ terterntu populasi infeksi cronis akan konstan di titik 0 .

Dari Gambar 3 terlihat bahwa populasi kanker mengalami kenaikan pada kondisi awal, hal ini disebabkan karena adanya penambahan individu dari populasi terinfeksi cronis. Setelah itu individu pada populasi kanker mengalami kematian secara alami dan kematian karena penyakit kanker. Pada $\mathrm{t}$ tertentu populasi kanker konstan pada $t$ tertentu dimana penyakit kanker tersebut belum hilang dari populasi.

Dari Gambar 3 terlihat bahwa populasi sembuh atau recovered mengalami kenaikan pada kondisi awal, hal ini disebabkan karena adanya penambahan individu dari populasi terinfeksi, populasi teninfeksi cronis dan individu yang telah divaksinasi. Kemudian populasi recovered akan mengalami penurunan, hal ini disebabkan sebagian individu mengalami kematian secara alami.

\section{Kesimpulan}

Dari penelitian diperoleh model SICKR pada penyebaran penyakit hepatitis dan kanker hati. Analisis model menghasilkan titik tetap bebas penyakit dan titik tetap endemik serta anlalisis kesetimbangan beban penyakit dan titik tetap endemik. Selanjutnya untuk memperkuat analisis model maka ditambahkan simulasi dari model SICKR menggunakan software maple dengan beberapa nilai $R_{0}$.

Bedasarkan hasil pembahasan diatas dapat disimpulkan bahwa dinamika populasi penyebaran penyakit terjadi dalam dua kondisi yaitu kondisi $\mathrm{R}_{0}<1$ yang menunjukkan bahwa penyebaran penyakit hepatitis B dan kanker hati tidak menyebar dan kondisi $\mathrm{R}_{0}>1$ yang menyebabkan penyebaran pada penyakit hepatitis $\mathrm{B}$ dan kanker hati.

\section{Referensi}

[1] World Health Organization, 2018, Tersedia di https://www.who.int/immunization/diseaseas/hepatitis/en.

[2] World Health Organization, 'Hepatitis B. World Health Organization Fact Sheet N $2042008^{\prime}, \quad$ Tersedia di http://www.who.int/mediacentre/factsheets/fs204/en/index/.html

[3] Warta, Katiga, Mengenal Hepatitis Di Tempat Kerja. Edisi 6, 2012

[4] Cahyono. Suharjo, Hepatitis B. Yogyakarta: Kansius, 2010.

[5] Soewignjo. Soemoharjo, Hepatitis Virus B. Jakarta: EG, 2008. 
[6] [Kemenkes] Kemetrian Kesehatan Repoblik Indonesia. ( 26 April 2016). Sebagian Besar Kematian akibat Hepatitis Virus Berhubungan dengan Hepatitis B dan C Kronis. http//:www.depkes.go.id/article/view/16042700001/ Sebagian-BesarKematian-akibat-Hepatitis-Virus-Berhubungan-dengan-Hepatitis-b-dan-c-Kronis.

[7] Heesterbeek. Diekman O, "Mathematical Epidemiology of Infection Diseases" USA: John Wiley and Son, Ltd.

[8] D. Larasati dan Redemtus. Tjahjana, "Analsis Model Matematika untuk Penyebaran Virus Hepatitis B (HBV)", 2012.

[9] D. Pujaningrum, "Model Metematika Hubungan antara hepatitis B dan Kanker Hati “,Universitas Islam Negeri Sunan Kalijaga, 2016.

[10] T.Syamsuddin, Pemodelan Matematika dalam Dinamika Populasi. Makassar: Dua Satu Press, 2013.

[11] R. Resmawan and N. Nurwan, "Konstruksi Bilangan Reproduksi Dasar pada Model Epidemik SEIRS-SEI Penyebaran Malaria dengan Vaksinasi dan Pengobatan," J. Mat. Integr., vol. 13, no. 2, p. 105, Sep. 2017.

[12] Ault. J.C dan Ayres. Frank, Persamaan Diferensial dalam satuan SI Metric. Jakarta: Erlangga, 1990.

[13] Lawrence. Perko, Differetial Equations and Dynamical Systems. USA: Springer 2020. 